sity, collected by Dr. P. P. Babiy. He has also seen specimens from Woodworth Lake, Fulton Co., N. Y. (C. P. Alexander) and from Lake Placid, N. Y. and Wilmington, N. Y. (J. M. Aldrich).

Chasmatonotus univittatus Coquillett

Fig. I

Described from Sitka, Alaska; five female specimens deposited in the U. S. Natioral Museum (Cat. No. 5195). The' writer has seen one specimen presented to Cornell University by the National Museum. He has also examined one specimen from Fieldbrook, Calif. (H. S. Barber). The wing is figured.

Chasmatonotus fascipennis Coquillett

\title{
Figs. 7 \& II
}

Described from 35 specimens collected at Kaslo Creek, B.C. Deposited in U. S. National Museum, No. 8376. Two specimens, male and female, have been given to the Cornell collection by the National Museum. The genitalia and wing of the male are figured.

Chasmatonotus hyalinus Coquillett.

A yellowish species with grayish hyaline wings. The other characters are indicated in the key. One male specimen, type No. 8.377, in U. S. National Museum. The writer has not seen the species.

The species of the genus, judging from the locality records, appear to be restricted to the Canadian zone. It is quite likely, therefore, that this genus will eventually prove to be well represented in the chironomid fama of Canada. REFERENCIS.

Coquillett, D. W. 1900. Papers from the Harriman Alaska Expedition, IX. Diptera, Proc. Wasth. Aca. Sc. $2: 395$.

Coruillett, D.W. 1905. New nematocerous Diptera from North America, J. N. Y. Ent. Soc. $13: 66$.

Johannsen O. A. 1905. Aquatic nematocerous Diptera. II. Chironomidae. N.Y. State Museum Biull. 86:166.

Loew, H. 1864. Diptera Ame icae septentrionalis indigena. Berl. Ent. Zeit. 8:50.

Malloch, J. R. 1915. The Chironomidar, or mimdigen of Illiniois, with particular refferences to the species accurring in the Illinois River. Bull. Ill. State Lab. Nat. History 10:499.

Osten Sacken, C. R. 1877. Western Diptera. Bull. U. S. Geol. Survey $3: 191 . \mid$

\section{A CORRECTION.}

BY C. N. AINSLIE

Referring to my paper on the panurgine bee Holcopasites stevensi $\mathrm{Cw} f \mathrm{~d}$., published in the May issue of the Canadian Entomologist, I have since been informed by Miss Grace Sandhouse of the National Museum that the species under discussion which I had supposed to be H. sterensi is really Holcopasites illinoiensis Robertson. The error is unfortunate and calls for an apology with this correction. However, it is very probable that the habits of the two species are not dissimilar and the studies of either one may aid in studying the other, when opportunity offers.

\section{OBI'TUARY}

\section{HAROLD BENJAMIN FANTHAM}

With the passing of Professor H. B. Fantham, M.A. (Cantab), D. Sc. (Lond), Strathcona Professor of Zoology, McGill University, our Entomological Society has lost a staunch friend and supporter. Dr. Fantham died at his home in Montreal on October 26th last in his sixty-first year, after a life devoted 
to scientific research and the teaching of zoology. His contributions to knowledge lay mainly in the field of protozoology but he always displayed a wide interest in all branches of his subject, as was manifest frcm the active part he took in the transactions of the Montreal Branch of the Society.

A native of Birmingham, England, Dr. Fantham came to McGill in January I933 from South Africa after fifteen years of outstanding service as Professor of Zoology and Comparative Anatomy in the University of the Witwatersrand, Johannesburg. Previous to this he had been engaged in important researches in protozoology. During the period rgro-19ï5, as Lecturer in Parasitology at the Liverpool School of Tropical Medicine, he investigated amoebiasis and Rhodesian sleeping sickness, and in 1913 was invited by the Government of the AngloEgyptian Sudan to work on spirochaetosis in Khartum. During the Great War he served as Protozoologist to His Majesty's forces in Salonika until he was invadided in I9I7, receiving his appointment in Johannesburg the same year.

During the course of his career, Dr. Fantham published nearly two hundred papers, some of them in collaboration with his wife, Dr. Annie Porter, berself a distinguished scientist. Some of these studies included work on. insects, as in a notable series of papers he added to the knowledge of the protozoan parasites of insects, especially in connection with the rosema disease of hive bees and the pathogenicity of the causal organism, Nosemo apis, to other species of insects. His work in parasitology led him to study the insects affecting man, while his keen interest in the embryology of insects has been reflected in the work of some of his pupils.

While at McGill Dr. Fantham acted as Chairman of the I.yman BBequest Committee. Members of the local Branch greatly benefited from his regular attendance at the monthly meetings; his annual talk to the group on some aspect of entomology was always a source of inspiration. His sympathetic concern for the welfare of his students has caused us to mourn him not only as a teacher but also as a friend.

H. A. U. MONRO.

Mailed Saturday, December 4th, I937. 